\title{
CHIEF EDITOR'S NOTE ON ADMINISTRATIVE JUSTICE IN BRICS COUNTRIES
}

\author{
DMITRY MALESHIN, \\ Lomonosov Moscow State University (Moscow, Russia)
}

DOI: 10.21684/2412-2343-2016-3-2-5-5

Recommended citation: Dmitry Maleshin, Chief Editor's Note on Administrative Justice in BRICS Countries, 3(2) BRICS Law Journal 5-5 (2016).

Administrative justice is a special type of dispute resolution concerned with the exercise of public power. To deal with disputes arising within this area, two different models for adjudicating cases are commonly found: administrative courts and specialized courts within the general courts system.

Most BRICS countries have adopted the specialized courts model, with the cases heard by their courts of general jurisdiction. None of the BRICS countries has adopted the administrative courts model.

In some countries, special laws regulate the proceedings. In Russia, China, and South Africa legislative acts on administrative procedure have been adopted. For IberoAmerica, there is the Model Code of Administrative Procedure and Administrative Justice.

Administrative justice in a comparative context was the topic of the II Siberian Legal Forum, organized by Tyumen State University, from 29-30 September 2016. BRICS Law Journal as one of the organizers of the conference devotes this issue to the development of administrative legal proceedings in BRICS as well as in other countries. It is pleased to publish the national reports on administrative justice in Brazil, Argentina, Spain, France, Italy, Poland and Russia. 